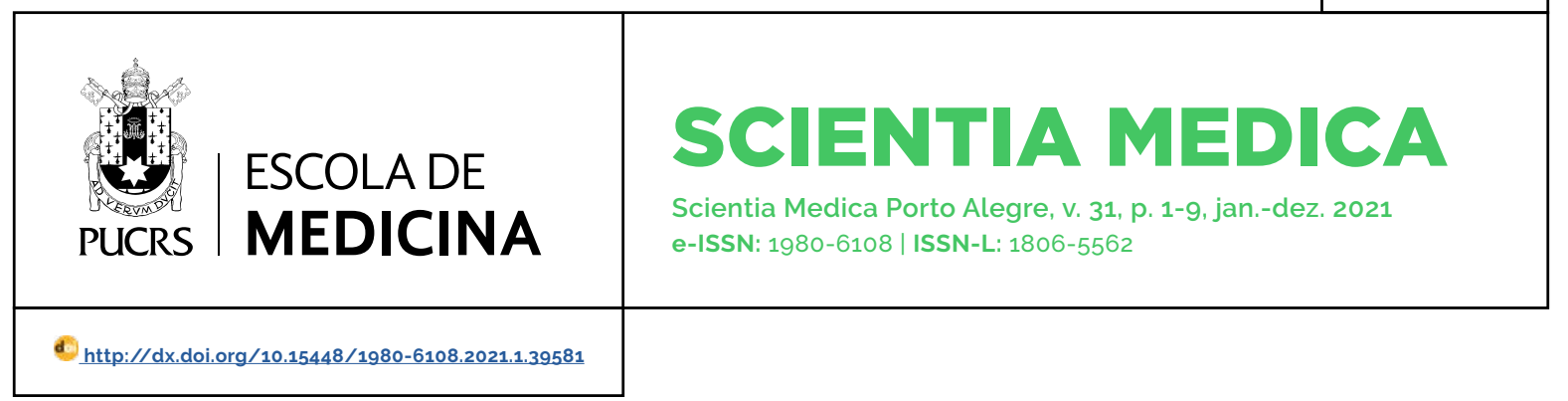

RESEARCH ARTICLE

\title{
Etiological investigation of genetic cause in autism spectrum disorder
}

\author{
Investigação etiológica de causa genética na perturbação do espetro do autismo
}

\section{Carla Andreia Esteves Fernandes $^{1}$ \\ orcid.org/0000-0002-4358-8743 \\ carla.ae.fernandes@gmail.com}

\section{Ana Francisca Henriques Cardoso ${ }^{2}$ orcid.org/0000-0002-1251-7416 ana_francisca2@hotmail.com}

\section{Caroline Reis Lopes ${ }^{2}$ orcid.org/0000-0002-5195-8425 reislopescaroline@hotmail.com}

\section{Margarida Maria Videira Henriques $^{2}$} orcid.org/0000-0003-4888-0396 margaida@hotmail.com

\section{Ester Preciosa Maio Nunes Pereira ${ }^{2}$} orcid.org/0000-0001-5956-0940 esterpmnpereira@gmail.com

Received on: November, $20^{\text {th }}$ 2020

Approved on: April, $16^{\text {th }} 2021$ Published on: May, $27^{\text {th }} 2021$

\begin{abstract}
AIMS: The aims of this study were to characterize the etiological investigation of genetic cause in the autism spectrum disorder and to determine the factors related to its identification.

METHODS: A retrospective descriptive study, with an analytical component, included children and adolescents with autism spectrum disorder followed in consultation at a level 2 hospital, between November 2017 and October 2019. The following variables were analyzed: age, sex, age at the first consultation, family history, objective examination, cognitive assessment, etiological investigation of genetic cause and etiological diagnosis of genetic cause. Statistical analysis was performed using the SPSS ${ }^{2}$ V23 program (significance level 0.05).
\end{abstract}

RESULTS: We identified 153 children with autism spectrum disorder, of which 48 underwent a genetic cause investigation: 45 performed microarray analysis (15.6\% pathogenic); 42 carried out a molecular study of the Fragile $X$ syndrome (one altered); two performed sequencing of the methyl CPG binding protein 2 (MECP2) gene (one altered). The diagnosis of genetic cause was made in $18.8 \%$ of the sample. The identification of the etiology of a genetic cause was related to global development delay/intellectual disability $(p=0.04)$ and the presence of relevant family history $(p=0.005)$.

CONCLUSIONS: The diagnostic yield of the genetic study was higher in patients with a global development delay /intellectual disability and in patients with relevant family history.

KEYWORDS: Autism Spectrum Disorder, Neurodevelopmental Disorders, Genetic Testing

\section{RESUMO}

OBJETIVOS: Os objetivos deste estudo foram caracterizar a investigação etiológica de causa genética na perturbação do espetro do autismo e determinar os fatores que se relacionam com a sua identificação.

MÉTODOS: Um estudo retrospetivo descritivo, com componente analítica, incluiu crianças e adolescentes com perturbação do espetro de autismo seguidos em consulta num hospital nivel 2 entre novembro de 2017 e outubro de 2019. As seguintes variáveis foram analisadas: idade, sexo, idade na primeira consulta, antecedentes familiares, exame objetivo, avaliação cognitiva, investigação etiológica de causa genética e diagnóstico etiológico de causa genética. A análise estatística foi realizada utilizando o programa SPSS ${ }^{2} V 23$ (nivel de significância 0,05).

RESULTADOS: Identificámos 153 crianças com perturbação do espetro de autismo, das quais 48 realizaram investigação etiológica de causa genética: 45 realizaram microarray (alterações patogénicas 15,6\%); 42 realizaram estudo molecular da sindrome X-Frágil (um alterado); dois realizaram sequenciação do gene MECP2 (um alterado). O diagnóstico de causa genética foi feito em $18,8 \%$ da amostra. A identificação de etiologia de causa genética relacionou-se com défice intelectual/atraso global do desenvolvimento psicomotor $(p=0,04)$ e com a presença de antecedentes familiares relevantes $(p=0,005)$. 
CONCLUSÕES: A rentabilidade diagnóstica do estudo genético foi superior em doentes com atraso global do desenvolvimento psicomotor/défice intelectual associado e com antecedentes familiares relevantes.

PALAVRAS-CHAVE: Transtorno do Espetro Autista, Distúrbios do Neurodesenvolvimento, Testes genéticos

ABBREVIATIONS: ASD, Autism Sectrum Disorder; CNV, Copy Number Variations; GDD, Global Development delay; ID, Intellectual Disability; MECP2, methyl CpG binding protein 2; PTEN, phosphatase and tensin homologue.

\section{INTRODUCTION}

The first description of autism spectrum disorder (ASD) was made by Leo Kanner, in 1943 (1), who identified 11 children with extreme inability to establish adequate social interactions, having assigned the designation of early childhood autism (2). Since then, this concept has suffered several changes and many definitions have been proposed to date (3). ASD is a complex neurodevelopmental disorder, constituting one of today's diagnostic and therapeutic challenges. It is characterized by impaired social interaction and communication, as well as the presence of restricted and repetitive behaviors. The diagnostic criteria defined in the Diagnostic and Statistical Manual of Mental Disorders, Fifth Edition (4) are: 1) Persistent deficits in social communication and social interaction across multiple contexts, as manifested by the following, currently or by history: a) social-emotional reciprocit, b) nonverbal communicative behaviors used for social interaction, c) developing, maintaining, and understand relationships; 2) Restricted, repetitive patterns of behavior, interests, or activities, as manifested by at least two of the following, currently or by history: a) stereotyped or repetitive motor movements, use of objects, or speech, b) insistence on sameness, inflexible adherence to routines, or ritualized patterns of verbal or nonverbal behavior, c) highly restricted, fixated interests that are abnormal in intensity or focus, d) hyper- or hyporeactivity to sensory input or unusual interest in sensory aspects of the environment; 3) Symptoms must be present in the early developmental period; 4) Symptoms cause clinically significant impairment in social, occupational, or other important areas of current functioning; 5) These disturbances are not better explained by intellectual disability or global developmental delay.

The number of children diagnosed with ASD has increased significantly in recent years (5). The 2017 World Health Organization report shows that, worldwide, 1 in 160 children has ASD (6). Its prevalence is around $1-2 \%$, with a ratio between male gender and female gender of 4-5:1 (7).

Although the etiology of ASD is not yet fully defined, most studies focus on genetic etiology, perhaps because ASD is one of the neurodevelopmental disorders highly heritable. Studies with families and twins suggest that heritability is around $50 \%$ (ranging from 26 to 93\%) (5). However, only 10$20 \%$ of cases have an identified genetic cause (8).

Considering the databases and recently published articles, about 1000 genes are implicated in ASD $(9,10)$. This disorder has been associated with polygenic variants, single nucleotide variants, copy number variations (CNV) and chromosomal abnormalities (10). However, it remains unclear how variations and different genes contribute to the great heterogeneity of the phenotype (11). Each gene represents $<1 \%$ of the cases and none showed complete specificity for ASD, with several genes involved in multiple neurodevelopmental disorders (12).

In the etiological investigation of ASD, the American College of Medical Genetics and Genomics recommends performing microarray in all cases, molecular study of Fragile $X$ syndrome in boys and specific genetic study in particular cases: phosphatase and tensin homologue (PTEN) gene (if there is macrocephaly) and methyl CpG binding protein 2 (MECP2) gene (in girls with intellectual deficit) (13). The evolution of microarray technology enabled the rapid detection of structural changes, namely CNV in the human genome. This technique allows for the detection of microdeletions and microduplications whose size is too small to be identified by the karyotype, being one of the most used technologies today $(7,14)$.

The aims of this study were to characterize the etiological investigation of cause genetics in ASD performed in patients followed at a level 2 hospital 
and determine the factors that relate to the identification of the etiology of genetic cause in ASD.

\section{METHODS}

We carried out a retrospective and descriptive study, with an analytical component.

The sample included children and adolescents with ASD followed up in Pediatrics consultations at a level 2 hospital, who underwent an etiological investigation of genetic cause between November 2017 and October 2019. All the patients fulfilled the Diagnostic and Statistical Manual of Mental Disorders, Fifth Edition diagnostic criteria for ASD (4). Diagnostic was confirmed with the diagnostic tools Autism Diagnostic Observation Schedule, Second edition and the Autism Diagnostic Interview-Revised.

We analyzed the variables: age at the first consultation, sex, family history, objective examination, assessment of psychomotor and/or cognitive development, etiological investigation of genetic cause and etiological diagnosis of genetic cause. Sociodemographic data were obtained by consulting the computer records (SClínico Hospitalar ${ }^{\mathrm{TM}}$ program) performed during follow-up consultations, where the children were subjected to a detailed objective examination and with attention to the presence of dysmorphisms.

All children and adolescents underwent assessment of psychomotor and/or cognitive development. We defined children with global development delay (GDD) as those aged five years or less, who had a significant delay in reaching the developmental milestones compared to what was expected for their chronological age ( $>$ two standard deviations below the average) in two or more areas of development; and children with intellectual disability (ID) were those with intellectual functioning significantly below the average assessed in a psychometric test $(I Q<70)$ and associated with a deficit in adaptive functioning. The instruments used were: Griffiths Mental Development Scales, third version; Wechsler Preschool and Primary Scale of Intelligence - Revised; Wechsler Intelligence Scale for Children, third version and Vineland Adaptive Behavior Scales.
Children and adolescents underwent blood collection for microarray and/or molecular study Fragile $X$ syndrome and/or specific genetic study (sequencing of MECP2 and PTEN genes, if indicated). Microarray technology enabled the rapid detection of structural changes in the human genome. This technique allows for the detection of microdeletions and microduplications and can be used to detect unbalanced regions of the genome. ASD is a common comorbid condition in children with Fragile $X$ syndrome so this genetic disorder should be considered. MECP2 is located on the $X$ chromosome and regulates brain function, particularly cognitive abilities. Girls with ASD have been found to have pathogenic mutations in this gene, so sequencing of MECP2 is indicated in girls with ID. Individuals with ASD who had pathogenic PTEN mutations also had macrocephaly, therefore, it is suggested that PTEN testing be reserved for patients with ASD with macrocephaly.

The microarray platforms used by the laboratory were Affymetrix CytoScan ${ }^{\mathrm{TM}} 750 \mathrm{~K}$ and BlueGnome ISCA 6oK CytoChip. CNV have been classified as pathogenic, likely pathogenic, uncertain significance, likely benign, benign, according to the criteria established by the American College of Medical Genetics Standards and Guidelines (15).

The statistical analysis was performed using the IBM SPSS Statistics 23 program (significance level 0.05).

\section{RESULTS}

We identified 153 children and adolescents with ASD, of which 48 (31.3\%) underwent etiological investigation of genetic cause. Of the total children and adolescents with ASD, 126 (82.4\%) were male and 27 (17.6\%) were female, with a ratio of $4.6: 1$ boys:girls. The median age at the first consultation was 3.52 years, with a minimum age of 10 months and a maximum age of 15 years. Regarding the assessment of psychomotor and cognitive development, of the 59 children aged five or less, 37 (62.7\%) had GDD, and of the 94 children aged six or more, 45 (47.9\%) had ID. Of the total children and adolescents with GDD/ID, who underwent etiological investigation, 28.5\% 
had a diagnosis of identified genetic cause. Dysmorphisms were identified in 39 (25.5\%) children. Regarding anthropometric data, 12 (7.8\%) had tall stature, three (2.0\%) had short stature, five (3.3\%) presented macrocephaly and two (1.3\%) microcephaly. In 25 cases (16.3\%) there was an important family history, namely neurodevelopmental or neurological pathology in first-degree relatives.

Regarding the etiological investigation of genetic cause carried out (Figure 1): 45 children and adolescents underwent a microarray that was altered in 19 children, seven (15.6\%) with
CNV classified as pathogenic and 12 with CNV classified as uncertain significance (Table 1); 42 performed a molecular study of Fragile $X$ syndrome, altered in one child; two girls sequenced the MECP2 gene, altered in one child; a boy with macrocephaly performed PTEN gene sequencing, which was normal. Thus, of the total of 48 children and adolescents with ASD who underwent etiological investigation of genetic cause, the etiological diagnosis was made in nine (18.8\%) of them. Their characterization is shown in Table 2.

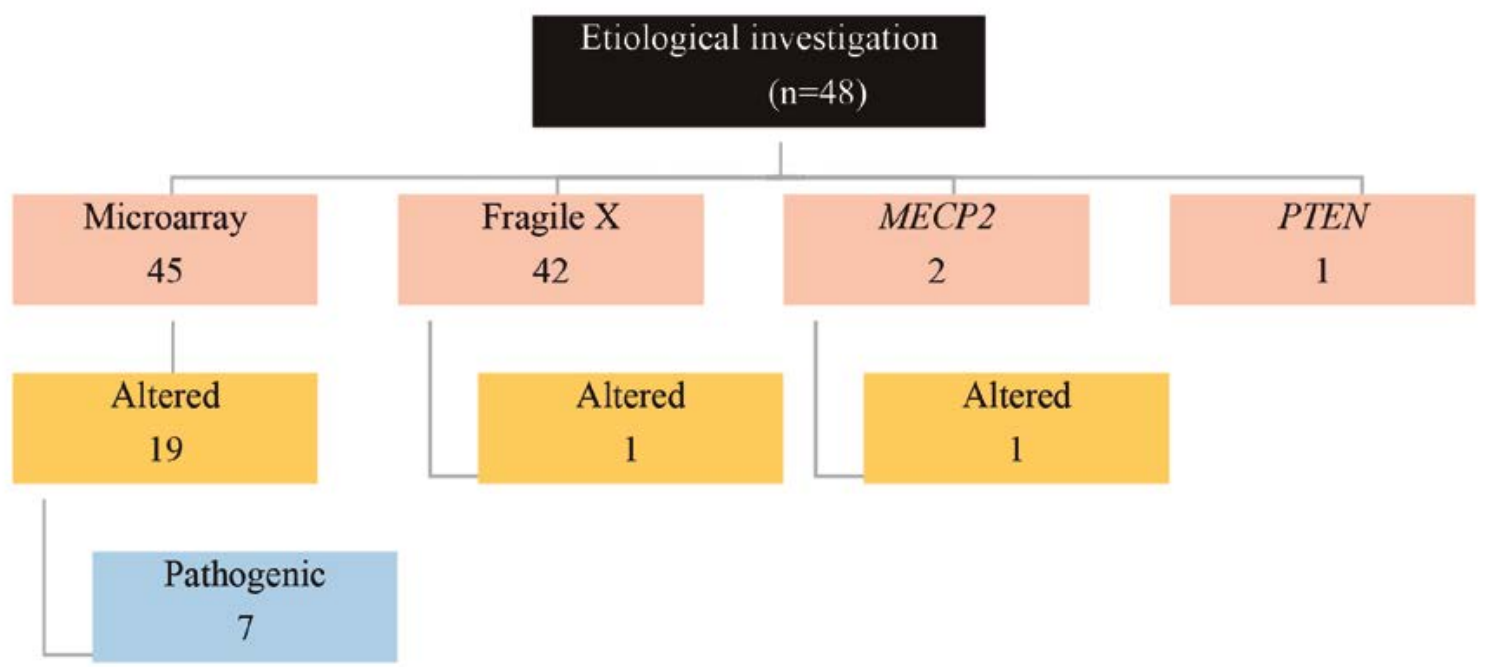

Figure 1 - Etiological investigation of genetic cause at a level 2 hospital. MECP2, methyl CpG binding protein 2; PTEN, phosphatase and tensin homologue.

TABLE 1 - Copy number variations of children and adolescents who underwent a microarray.

\begin{tabular}{|c|c|c|c|c|}
\hline $\begin{array}{c}\text { Chromosomal } \\
\text { Location }\end{array}$ & CNV type & Size & Associated disease & Sex \\
\hline \multicolumn{5}{|l|}{ Pathogenic } \\
\hline 15q11.2q13.1 & Duplication & $4.9 \mathrm{Mb}$ & 15q11-q13 microduplication syndrome & M \\
\hline 15q11.2q13.1 & Duplication & $4.9 \mathrm{Mb}$ & 15q11-q13 microduplication syndrome & M \\
\hline 15q11.2q13.1 & Duplication & $4.9 \mathrm{Mb}$ & 15q11-q13 microduplication syndrome & M \\
\hline 16p13.11 & Deletion & $1.4 \mathrm{Mb}$ & 16p13.11microdeletion syndrome & M \\
\hline $6 q 27$ & Deletion & $1.8 \mathrm{Mb}$ & $6 q$ terminal deletion syndrome & M \\
\hline $1 q 21.1$ & Duplication & $2.4 \mathrm{Mb}$ & 1q21.1 microduplication syndrome & $\mathrm{F}$ \\
\hline $17 \mathrm{p} 12$ & Copy number gain & $1,4 \mathrm{Mb}$ & Charcot-Marie-Tooth disease & M \\
\hline
\end{tabular}


TABLE 1 - Copy number variations of children and adolescents who underwent a microarray (cont.).

\begin{tabular}{|c|c|c|c|c|}
\hline $\begin{array}{l}\text { Chromosomal } \\
\text { Location }\end{array}$ & CNV type & Size & Associated disease & Sex \\
\hline \multicolumn{5}{|c|}{ Uncertain significance } \\
\hline 16p13.3 & Copy number gain & $502 \mathrm{~Kb}$ & & \\
\hline 12p11.23 & Duplication & $212.5 \mathrm{~Kb}$ & & \\
\hline $12 q 24.33$ & Copy number gain & $670 \mathrm{~Kb}$ & & \\
\hline $15 q 15.2$ & Copy number gain & $106 \mathrm{~Kb}$ & & \\
\hline $6 p 12.3$ & Copy number gain & $1400 \mathrm{~Kb}$ & & \\
\hline 18p11.21 & Deletion & $390 \mathrm{~Kb}$ & & \\
\hline 22q11.1 & Duplication & $116.3 \mathrm{~Kb}$ & & \\
\hline $6 p 21.31$ & Duplication & $316 \mathrm{~Kb}$ & & \\
\hline 7936.1 & Deletion & $205 \mathrm{~Kb}$ & & \\
\hline $15 q 14$ & Duplication & $1930 \mathrm{~Kb}$ & & \\
\hline $2 p 23.1$ & Deletion & $224 \mathrm{~Kb}$ & & \\
\hline Xp21.2 & Copy number gain & $226 \mathrm{~Kb}$ & & \\
\hline
\end{tabular}

CNV, copy number variation; F, female; $M$, male.

TABLE 2 - Characterization of etiological investigation of genetic cause

\begin{tabular}{|c|c|c|c|c|c|}
\hline sex & $\begin{array}{l}\text { ID / } \\
\text { GDD }\end{array}$ & $\begin{array}{l}\text { Clinical } \\
\text { features }\end{array}$ & Family history & Associated disease & OMIM \\
\hline M & Yes & Short stature & 2 brothers ASD & 15q11-q13 microduplication syndrome & \# 608636 \\
\hline M & Yes & Dysmorphisms & 2 brothers ASD & 15q11-q13 microduplication syndrome & \# 608636 \\
\hline M & Yes & - & 2 brothers ASD & 15q11-q13 microduplication syndrome & \# 608636 \\
\hline M & No & Dysmorphisms & - & 16p13.11microdeletion syndrome & - \\
\hline M & Yes & - & - & $6 \mathrm{q}$ terminal deletion syndrome & - \\
\hline $\mathrm{F}$ & Yes & Dysmorphisms & 1 brother ASD & 1q21.1 microduplication syndrome & \# 612475 \\
\hline M & Yes & Dysmorphisms & - & Fragile $X$ syndrome & \# 300624 \\
\hline $\mathrm{F}$ & Yes & $\begin{array}{l}\text { Macrocephaly/ } \\
\text { Tall stature }\end{array}$ & - & Rett syndrome & \# 312750 \\
\hline M & Yes & Tall stature & - & Charcot-Marie-Tooth disease & \#118220 \\
\hline
\end{tabular}

ASD, autism spectrum disorder; F, female; GDD, global development delay; ID, intellectual disability; M, male.

The statistical analysis performed in order to determine factors related to the identification of etiology of genetic cause in ASD (Table 3 ) allowed us to infer that: the identification of the etiology of genetic cause was related to the presence of
GDD/ID ( $p=0.04)$ and with the existence of relevant family history ( $p=0.005)$; and the presence of pathogenic $\mathrm{CNV}$ in the microarray was related to the existence of relevant family history $(p=0.001)$. 
TABLE 3 - Factors related to the identification of etiology of genetic cause in autism spectrum disorder ${ }^{\star}$

Microarray with pathogenic variant $(n=7)$
Etiological diagnosis of genetic cause present $(n=9)$

\begin{tabular}{lll}
\hline ID/GDD & $\mathrm{p}=0.139$ & $\mathrm{p}=0.04$ \\
Dysmorphisms & $\mathrm{p}=0.238$ & $\mathrm{p}=0.135$ \\
Tall stature & $\mathrm{p}=0.855$ & $\mathrm{p}=0.620$ \\
Short stature & $\mathrm{p}=0.147$ & $\mathrm{p}=0.247$ \\
Macrocephaly & $\mathrm{p}=0.551$ & $\mathrm{p}=0.488$ \\
Microcephaly & $\mathrm{p}=0.551$ & $\mathrm{p}=0.488$ \\
Relevant family history & $\mathrm{p}=0.001$ & $\mathrm{p}=0.005$ \\
\hline
\end{tabular}

GDD, global development delay; ID, intellectual disability. *Teste Pearson Chi-Square.

\section{DISCUSSION}

Our study showed a clear predominance of boys in children and adolescents with ASD, with a ratio of 4.6:1, which is in line with what is described in the current literature $(2,7,16)$. Several hypotheses have been suggested to explain this difference between genders, of which the "extreme male brain", the "female protective effect" and the "female autism phenotype" stand out (17). The "extreme male brain" hypothesis argues that ASD is an extreme expression of physiological and psychological characteristics of the male brain (18), which resulted from exposure to fetal testosterone $(19,20)$. The "female protective effect" theory postulates that girls need a greater mutational load to manifest the ASD phenotype in relation to boys (19). This latter hypothesis is supported by studies that show that girls have an excess of CNV in deletion, mutations that are more harmful to the genes than those found in boys (19), which in our study was not found, in a probable relationship with the small sample number. The "female autism phenotype" is slightly different from the conventional one. For example, girls have less restrictive interests than boys with ASD, which makes the diagnosis difficult (17). There is yet another factor that potentially contributes to this bias introduced by health professionals, since they associate ASD with the male gender, its sensitivity decreasing in what concerns symptoms in girls (17).

The most prevalent ASD comorbidities in our sample were neurodevelopment disorders, namely GDD and ID, with a combined prevalence of around $50 \%$, a percentage also described in other series $(3,5,16)$.

In our study, the yield of the microarray was $15.6 \%$, slightly higher than what is described in most studies: Shen et al., in a cohort of 933 patients, identified pathogenic mutations in $7 \%$ of the microarrays (21); Tammimies et al., in a sample of 258 patients, obtained a yield of 9.3\% (22); in a Portuguese study with 253 patients, Monteiro et al. describe a detection rate of $11.46 \%$ (14); Kalsner et al., in 100 patients, obtained a yield of 12\% (23). However, there are also studies with a higher yield, such as the one by Schaefer et al., who found pathogenic variants in $22 \%$ of 68 patients (24).

Currently, there are few $\mathrm{CNV}$ reported in the Online Mendelian Inheritance in Man database associated with isolated ASD phenotypes. These are characterized by incomplete penetrance and variable expressiveness (25). The 15q11-q13 duplication is one of them, being the CNV more regularly described in the studies $(10,26)$, and occurring in 1-3\% of children with ASD, usually of maternal inheritance (7, 9). In our study, this mutation is present in three siblings with ASD and ID, of maternal heritability. The 1q21.1 region is also frequently associated with ASD in several studies $(16,27)$, including a recognized phenotype, which is manifested by ASD, ID and dysmorphisms. In our sample, we found a case that corresponds to 
the described genotype and phenotype. When one or more unknown $\mathrm{CNV}$ are detected in individuals with ASD, one can speculate about the genotype-phenotype association, based on the function and expression of the genes involved. Nevertheless, the etiological contribution of the variant cannot be proven with certainty (25), thus having an uncertain significance.

The etiological investigation of genetic causes in children and adolescents with ASD has been increasing in recent years, with an estimated yield proposed by Schaefer and Mendelsohn, in the American College of Medical Genetics Standards and Guidelines, of $30-40 \%$ (13). In our study, the children who underwent research have an etiology of genetic cause identified in $18.8 \%$, which indicates that the values suggested by Schaefer and Mendelsohn may be higher than those found in a real population of children with ASD. This is also supported in other studies, whose yield was $12-25 \%(14,28)$.

About $5-10 \%$ of children with ASD have associated monogenic disorders or syndromes, the most common being Fragile $X$ syndrome, diagnosed in about $1.5-3 \%$ of children with ASD (7). In our study, we identified a boy with Fragile $X$ syndrome, corresponding to $2 \%$ of children and adolescents with ASD who underwent etiological investigation, a value close to that described by Shen et al. in a cohort of 933 patients: 0.5\% (21).

Mutations in the MECP2 gene are responsible for Rett syndrome, which is diagnosed in $1-4 \%$ of girls with ASD $(7,14)$. This is in line with that found in our sample, which was $3.7 \%$, corresponding to one girl in the total of girls with ASD followed in consultation. Another syndrome also associated with ASD, which should be excluded in the presence of macrocephaly, is the PTEN hamartoma tumor syndrome, present in up to $20 \%$ of patients with ASD and macrocephaly (8). However, in our sample, it was not diagnosed in any patient, it may be related with the low prevalence of macrocephaly in our study $(3.3 \%)$.

In our study, the identification of the etiology of a genetic cause was related to the presence of ID or GDD and family history of neurodevelopment/ neurological pathology. These results are in line with several studies that claim that the diagnostic yield is higher in patients with ASD with accompanying ID. Monteiro et al. describe the presence of pathogenic $\mathrm{CNV}$ in the microarray in $41.35 \%$ of the patients with ID and ASD in the sample (14), a value slightly higher than that of our sample, which was $28.5 \%$. This can be explained by the small number of children with ASD who carried out etiological investigation. These studies also report that the presence of dysmorphisms, macro or microcephaly, increases the probability of genetic etiology, but such an association was not found in our study $(18,29)$.

ASD is one of the most hereditable neurodevelopment disorders (10), estimated at 51-85\%, (25) in agreement with the association found in our study between identification of etiology of genetic cause and the presence of family history of neurodevelopment/neurological pathology.

The limitations of our study are due to the small sample size and its retrospective nature. Another important limitation was the fact that the etiological investigation of a genetic cause was not carried out uniformly in all children.

It is important to carry out the etiological investigation of ASD in a systematic way in order to adjust surveillance, determine a more reliable prognosis, allow genetic counseling and optimize resources (14). Identifying an etiology for the disorder also provides some emotional relief to the family putting an end to the diagnostic odyssey. In addition, it is crucial for the establishment of a therapeutic alliance with parents (2). Our study showed that the etiological investigation of a genetic cause is particularly important in the presence of associated ID/GDD or family history of neurodevelopment / neurological pathology, as is indicated in the Clinical Guidance Standard published by the Direção Geral de Sáude (30). In recent years, much progress has been made to understand the etiology of ASD and the study presented allowed to characterize the etiological investigation of genetic cause in ASD. However, further studies are needed to understand the genotype-phenotype relationship, essential to comprehend the molecular mechanisms of ASD 
(9), which in the near future may be the key to the development of new therapies.

\section{Notes}

Parto of this study was presented in the XXV Jornadas de Pediatria de Leiria e Caldas da Rainha, November, 29 - 30, 2018.

\section{Funding}

This study did not receive financial support from external sources

\section{Conflicts of interest disclosure}

The authors declare no competing interests relevant to the content of this study.

\section{Authors' contributions.}

All the authors declare to have made substantial contributions to the conception, or design, or acquisition, or analysis, or interpretation of data; and drafting the work or revising it critically for important intellectual content; and to approve the version to be published.

\section{Availability of data and responsibility for the results}

All the authors declare to have had full access to the available data and they assume full responsibility for the integrity of these results.

\section{REFERENCES}

1. Kanner L. Autistic disturbances of affective contact. Acta Paedopsychiatr. Acta Paedopsychiatr. 1968:35(4):100-36.

2. Al-Dewik N, Al-Jurf R, Styles M, Tathamouni S, Alsharshani $D$, Alsharshani $M$, et al. Overview and introduction to Autism Spectrum Disorder (ASD). Adv Neurobiol. 2020;24:342. https://doi.org/10.1007/978-3-030-30402-7_1.

3. Chaste P, Roeder K, Devlin B. The Yin and Yang of autism genetics: how rare de novo and common variations affect liability. Annu Rev Genomics Hum Genet. 2017:18:167-87. https://doi.org/10.1146/annurev-genom-083115-022647.

4. American Psychiatric Association. Diagnostic and statistical manual of mental disorders. 5th Edition Washington DC: American Psychiatric Association; 2013
5. Baumer N, Spence SJ. Evaluation and management of the child with autism spectrum disorder. Continuum. 2018;24(1):248-75. https://doi.org/10.1212/ CON.0000000000000578

6. World Health Organization. Regional Office for South-East Asia. WHO South-East Asia regional strategy on autism spectrum disorders [Internet]. New Delhi: World Heath House, 2017 [cited 2021 Apr 15]. Available from: https:// apps.who.int/iris/bitstream/handle/10665/259505/ 9789290225454-en.pdf? sequence=1\&isAllowed=y

7. Wiśniowiecka-Kowalnik B, Nowakowska BA. Genetics and epigenetics of autism spectrum disorder-current evidence in the field. J Appl Genet. 2019;60(1):37-47. https://doi.org/10.1007/s13353-018-00480-w

8. Busch RM, Srivastava S, Hogue O, Frazier TW, Klaas P, Hardan A, et al. Neurobehavioral phenotype of autism spectrum disorder associated with germline heterozygous mutations in PTEN. Transl Psychiatry. 2019;9(1):253. https://doi.org/10.1038/s41398-019-0588-1

9. Al-Dewik N, Alsharshani M. New horizons for molecular genetics diagnostic and research in autism spectrum disorder. Adv Neurobiol. 2020;24:43-81. https://doi. org/10.1007/978-3-030-30402-7_2

10. Bitar T, Hleihel W, Marouillat S, Vonwill S, Vuillame $M L$, Soufia $M$, et al. Identification of rare copy number variations reveals PJA2, APCS, SYNPO, and TAC1 as novel candidate genes in autism spectrum disorders. Mol Genet Genomic Med. 2019:7(8):e786. https:// doi.org/10.1002/mgg3.786

11. Toma C. Genetic Variation across phenotypic severity of autism. Trends Genet. 2020;36(4):228-31 https://doi. org/10.1016/j.tig.2020.01.005

12. McDiarmid TA, Belmadani M, Liang J, Meili F, Mathews EA, Mullen GP, et al. Systematic phenomics analysis of autism-associated genes reveals parallel networks underlying reversible impairments in habituation. Proc Natl Acad Sci USA. 2020;117(1):656-67. https://doi.org/10.1073/pnas.1912049116

13. Schaefer GB, Mendelsohn NJ; Professional Practice and Guidelines Committee. Clinical genetics evaluation in identifying the etiology of autism spectrum disorders: 2013 guideline revisions. Genet Med. 2013;15(5):399-407. https://doi.org/10.1038/gim.2013.32

14. Monteiro S, Pinto J, Mira Coelho A, Leão M, Dória $S$. Identification of copy number variation by Array-CGH in Portuguese children and adolescents diagnosed with autism spectrum disorders. Neuropediatrics. 2019:50(6):367-77. https://doi.org/10.1055/s-0039-1694797

15. Riggs ER, Andersen EF, Cherry AM, Kantarci S, Kearney $\mathrm{H}$, Patel A, et al. Technical standards for the interpretation and reporting of constitutional copy-number variants: a joint consensus recommendation of the American College of Medical Genetics and Genomics (ACMG) and the Clinical Genome Resource (ClinGen). Genet Med. 2020;22(2):245-57. https://doi.org/10.1038/ s41436-019-0686-8 
16. Woodbury-Smith M, Scherer SW. Progress in the genetics of autism spectrum disorder. Dev Med Child Neurol. 2018;60(5):445-51. https://doi.org/10.1111/dmcn.13717

17. Loomes R, Hull L, Mandy WPL. What is the male-to-female ratio in autism spectrum disorder? A systematic review and meta-analysis. J Am Acad Child Adolesc Psychiatry. 2017:56(6):466-74. https://doi.org/10.1016/i. jaac.2017.03.013

18. Jacquemont S, Coe BP, Hersch M, Duyzend $\mathrm{MH}$, Krumm N, Bergmann S, et al. A higher mutational burden in females supports a "female protective model" in neurodevelopmental disorders. Am J Hum Genet. 2014:94(3):41525. https://doi.org/10.1016/j.ajhg.2014.02.001

19. Zhang Y, Li N, Li C, Zhang Z, Teng H, Wang Y, et al. Genetic evidence of gender difference in autism spectrum disorder supports the female-protective effect. Transl Psychiatry. 2020;10(1):4. https://doi. org/10.1038/s41398-020-0699-8.

20. Baron-Cohen $\mathrm{S}$. The extreme male brain theory of autism. Trends Cogn Sci. 2002;6(6):248-54. https://doi. org/10.1016/s1364-6613(02)01904-6.

21. Shen Y, Dies KA, Holm IA, Bridgemohan C, Sobeih MM, Caronna EB, et al. Clinical genetic testing for patients with autism spectrum disorders. PediatriCS. 2010;125(4):e727-e735. https://doi.org/10.1542/ peds.2009-1684.

22. Tammimies K, Marshall CR, Walker S, Kaur G, Thiruvahindrapuram B, Lionel AC, et al. Molecular diagnostic yield of chromosomal microarray analysis and whole-exome sequencing in children with autism spectrum disorder. JAMA. 2015;314(9):895-903. https:// doi.org/10.1001/jama.2015.10078.

23. Kalsner L, Twachtman-Bassett J, Tokarski K, Stanley C, Dumont-Mathieu T, Cotney J, et al. Genetic testing including targeted gene panel in a diverse clinical population of children with autism spectrum disorder: Findings and implications. Mol Genet Genomic Med. 2018;6(2):171-85. https://doi.org/10.1002/mgg3.354.

24. Schaefer GB, Starr L, Pickering D, Skar G, Dehaai K, Sanger WG. Array comparative genomic hybridization findings in a cohort referred for an autism evaluation. J Child Neurol. 2010;25(12):1498-503. https://doi. org/10.1177/0883073810370479.

25. Vicari S, Napoli E, Cordeddu V, Menghini D, Alesi V. Loddo S, et al. Copy number variants in autism spectrum disorders. Prog Neuropsychopharmacol Biol Psychiatry. 2019:92:421-27. https://doi.org/10.1016/i. pnpbp.2019.02.012.

26. Nisar S, Hashem S, Bhat AA, Syed N, Yadav S, Azeem MW, et al. Association of genes with phenotype in autism spectrum disorder. Aging. 2019;11(22):10742-70. https://doi.org/10.18632/aging.102473.

27. Sanders SJ, He X, Willsey AJ, Ercan-Sencicek AG, Samocha KE, Cicek AE, et al. Insights into autism spectrum disorder genomic architecture and biology from 71 risk loci. Neuron. 2015:87(6):1215-33.https://doi.org/10.1016/i.neuron.2015.09.016.
28. Bourgeron, T. From the genetic architecture to synaptic plasticity in autism spectrum disorder. Nat Rev Neurosci. 2015;16(9):551-63. https://doi.org/10.1038/ nrn3992.

29. Capkova Z, Capkova P, Srovnal J, Staffova K, Becvarova $\mathrm{V}$, Trkova $\mathrm{M}$, et al. Differences in the importance of microcephaly, dysmorphism, and epilepsy in the detection of pathogenic CNV in ID and ASD patients. PeerJ. 2019:7:e7979 https://doi.org/10.7717/peerj.7979.

30. Portugal. Ministério da Saúde. Serviço Nacional de Saúde. Direção Geral de Saúde. Norma n 002/2019. Abordagem diagnóstica e intervenção na perturbação do espetro do autismo em idade pediátrica e no adulto [Internet]. Lisboa: Direção Geral de Saúde; 2019 [Cited $2021 \mathrm{Apr}$ 15]. Available from: https://normas. dgs.min-saude.pt/wp-content/uploads/2019/og/ Abordagem-Diagnostica-e-Intervencao-na-Perturbacao-do-Espetro-do-Autismo-em-Idade-Pediatrica-e-no-Adulto_2019.pdf

\section{Carla Andreia Esteves Fernandes}

Resident of Pediatrics, Centro Hospitalar e Universitário de Coimbra (CHUC), Coimbra, Portugal.

\section{Ana Francisca Henriques Cardoso}

Resident of Pediatrics, Centro Hospitalar de Leiria $(\mathrm{CHL})$, Leiria, Portugal.

\section{Caroline Reis Lopes}

Resident of Pediatrics, Centro Hospitalar de Leiria (CHL), Leiria, Portugal.

\section{Margarida Maria Videira Henriques}

Graduated Hospitalar Assistant of Pediatrics, Centro Hospitalar de Leiria (CHL), Leiria, Portugal

\section{Ester Preciosa Maio Nunes Pereira}

Hospitalar Assistant of Pediatrics, Centro Hospitalar de Leiria (CHL), Leiria, Portugal.

\section{Mailing address:}

Carla Andreia Esteves Fernandes

Centro Hospitalar de Coimbra

Rua Dr. Afonso Romão, s/n, 3000-602

Coimbra, Portugal. 